\title{
Diagnosis dan Penatalaksanaan Tumor Ganas Laring
}

\author{
Dolly Irfandy, Sukri Rahman
}

\begin{abstract}
Abstrak
Laring berperan dalam koordinasi fungsi saluran aerodigestif atas seperti bernafas, berbicara dan menelan. Laring terbagi tiga yaitu supraglotis, glotis dan subglotis. Laring merupakan daerah tersering kedua untuk kasus karsinoma sel skuamosa kepala-leher, biasanya berhubungan dengan tembakau dan alkohol. Lebih dari 95\% kasus tumor ganas laring adalah karsinoma sel skuamosa. Pasien tumor ganas laring datang dengan berbagai keluhan seperti disfonia, obstruksi jalan napas, disfagia, odinofagi dan hemoptisis. Diagnosis tumor ganas laring ditegakkan berdasarkan anamnesis, pemeriksaan klinis menggunakan endoskopi kaku, serat optik dan biopsi. Penatalaksanaan tumor ganas laring tergantung stadium dengan modalitas berupa operasi, kemoterapi, radiasi atau terapi kombinasi. Dilaporkan kasus laki-laki 53 tahun dengan karsinoma glotis stadium III (T3NOM0) squamous cell ca keratinized well differentiated. Penatalaksanaan pada pasien ini dengan melakukan laringektomi total.
\end{abstract}

Kata kunci: Tumor ganas laring, karsinoma, laringektomi, tembakau

\begin{abstract}
Larynx plays a certain role in coordinating functions of the upper aerodigestive tract, such as respiration, speech, and swallowing. The larynx is divided into three region; supraglottic, glottic, and subglottic. Larynx is the second most common site for squamous cell carcinoma in the head and neck and usually related to tobacco and alcohol exposure. Primary malignant tumors of the larynx are squamous cell carcinomas can found more than $95 \%$ of cases. Patients with laryngeal tumors usually present with complaints of hoarseness, respiratory obstruction, dysphagia, odynophagia and hemoptysis. Diagnosis of laryngeal cancer is made by medical history, clinical examination using a rigid or fiberoptic endoscope and biopsy. Management of laryngeal tumour depends on stadium with various modality included surgery, chemotheraphy, radiotheraphy or combined therapy. Reported case of 53 years old male with Glottic carcinoma of the larynx stage III (T3NOMO) squamous cell ca keratinized well differentiated is presented. The treatment undergoes with total laryngectomy.
\end{abstract}

Keywords: Laryngeal cancer, carcinoma, laryngectomy, tobacco

Affiliasi penulis : Bagian THT-KL Fakultas Kedokteran Universitas Andalas / RSUP Dr. M. Djamil Padang

Korespondensi : Dolly Irfandy, E-mail: d_irfandy@yahoo.com,Telp: : 081363489029

\section{PENDAHULUAN}

Laring memainkan peranan sentral dalam mengkoordinasikan fungsi saluran pencernaanpernafasan atas termasuk respirasi, berbicara dan menelan. Laring dibagi menjadi supraglotis, glotis, dan subglotis. Laring adalah tempat tersering kedua untuk kasus karsinoma sel skuamosa pada daerah kepala dan leher. ${ }^{1-3}$ Tumor ganas laring hingga saat ini masih menjadi masalah di bidang IImu Telinga Hidung
Tenggorok- Bedah Kepala dan Leher. Tumor ganas laring merupakan 1-2\% dari seluruh kejadian tumor ganas di seluruh dunia. Pada tahun 2011 diperkirakan 12.740 kasus baru tumor ganas laring di Amerika Serikat dan diperkirakan 3560 orang meninggal. ${ }^{1,4,5}$

Kasus tumor ganas laring di RS. M. Djamil Padang periode Januari 2011-Desember 2012 tercatat 13 kasus baru dan ditatalaksana dengan laringektomi total sebanyak 6 kasus. Kejadian tumor ganas laring berhubungan dengan kebiasaan merokok dan konsumsi alkohol. Pada individu yang mengkonsumsi keduanya, faktor resikonya menjadi sinergi dan kemungkinan terjadi kanker lebih tinggi. ${ }^{1,3,6-8}$ 
Karsinoma sel skuamosa merupakan jenis tumor ganas laring primer yang paling sering ditemukan, yaitu lebih dari 95\% kasus. Sisanya tumor yang berasal dari kelenjar ludah minor, neuroepithelial, tumor jaringan lunak dan jarang timbul dari tulang kartilaginosa laring. ${ }^{1,9}$ Karsinoma sel skuamosa laring merupakan hasil dari interaksi banyak faktor etiologi seperti konsumsi tembakau dan atau alkohol yang lama, bahan karsinogen lingkungan, status sosial ekonomi, pekerjaan yang berbahaya, faktor makanan dan kerentanan genetik. ${ }^{9}$ Terdapat beberapa modalitas terapi untuk menatalaksana kasus tumor ganas laring tergantung stadiumnya yaitu laringektomi parsial/total, kemo-radiasi atau terapi kombinasi. ${ }^{1,9-11}$

\section{LAPORAN KASUS}

Seorang pasien laki-laki 53 tahun (MR: 804329) datang ke poli THT-KL RSUP. M. Djamil tanggal 3 Desember 2012 yang sudah didiagnosis dengan squamous cell carcinoma keratinized well differentiated glotis stadium III $\left(\mathrm{T}_{3} \mathrm{~N}_{0} \mathrm{M}_{0}\right)$. Pada tanggal 29 Oktober 2012 yang lalu, sudah dilakukan trakeostomi emergensi terhadap pasien untuk mengatasi obstruksi jalan nafas atas derajat II yang disebabkan tumor laring di IGD RS. M. Djamil dilanjutkan dengan biopsi. Sebelumnya pasien sesak nafas sejak 1 bulan terakhir dan bertambah berat sejak 4 hari sebelum masuk rumah sakit. Suara serak sejak 1 tahun terakhir dan sebulan terakhir suara semakin serak dan mulai menghilang. Riwayat batuk berdarah dan batuk-batuk lama tidak ada. Riwayat minum obat lama tidak ada. Nyeri menelan dan gangguan menelan tidak ada. Penglihatan ganda tidak ada, hidung berdarah dan tersumbat tidak ada. Benjolan di leher, ketiak dan lipat paha tidak ada. Riwayat minum alkohol tidak ada. Tidak ada riwayat terpapar sinar radiasi. Tidak ada riwayat gangguan lambung. Riwayat merokok kretek 1 bungkus per hari selama \pm 30 tahun dan berhenti merokok sejak 1 bulan terakhir. Pada pemeriksaan fisik didapatkan kesadaran komposmentis kooperatif, tekanan darah $110 / 70 \mathrm{mmHg}$, nadi $80 \mathrm{x} /$ menit, frekuensi nafas 18x/menit. Pada pemeriksaan fisik telinga dan hidung dalam batas normal, pada leher kanul trakeostomi terpasang baik, tidak ada tanda infeksi, pasase udara lancar, massa tidak ada, tidak terdapat pembesaran kelenjar getah bening leher.

Pada hasil pemeriksaan telelaringoskopi 25 Oktober 2012: epiglotis tenang, aritenoid tenang, gerakan simetris, massa di plika ventrikularis kanankiri, massa plika vokalis kanan-kiri, gerakan terfiksir; rima glotis sempit; subglotis sukar dinilai (Gambar 1). Kesan; tumor glotis dan supra glottis dan pasien dianjurkan untuk biopsi tumor laring.

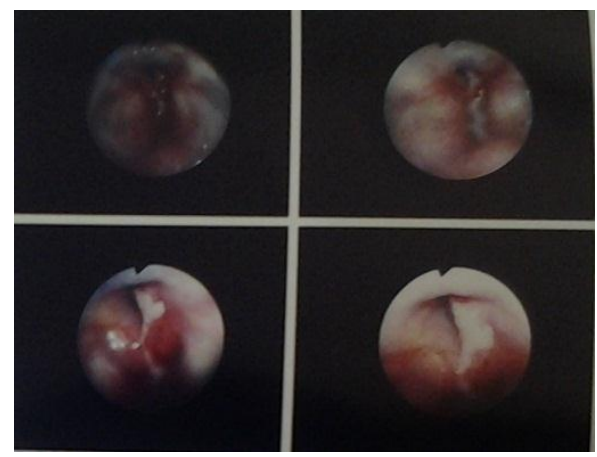

Gambar 1. Terlihat rima glotis sempit, massa diplika vokalis kanan-kiri pada hasil telelaringoskopi

Pemeriksaan tomografi komputer (TK) laring tanggal 8 November 2012 terlihat massa isodens inhomogen berbatas tak tegas dengan tepi ireguler pada laring disertai penyempitan airway (Gambar 2 dan 3), tepasang kanul trakeostomi di distal penyempitan tersebut, tak tampak pembesaran kelenjar limfe leher, kartilago intak, kesan tumor ganas laring.

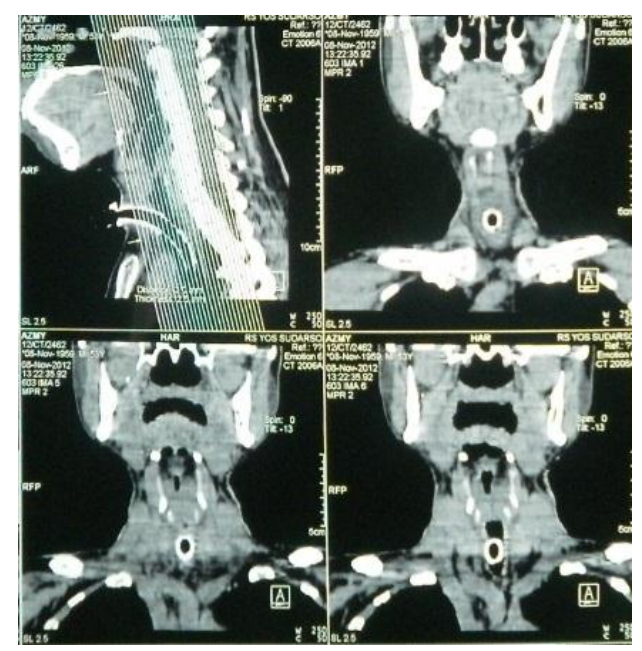

Gambar 2.TK potongan Koronal Laring 


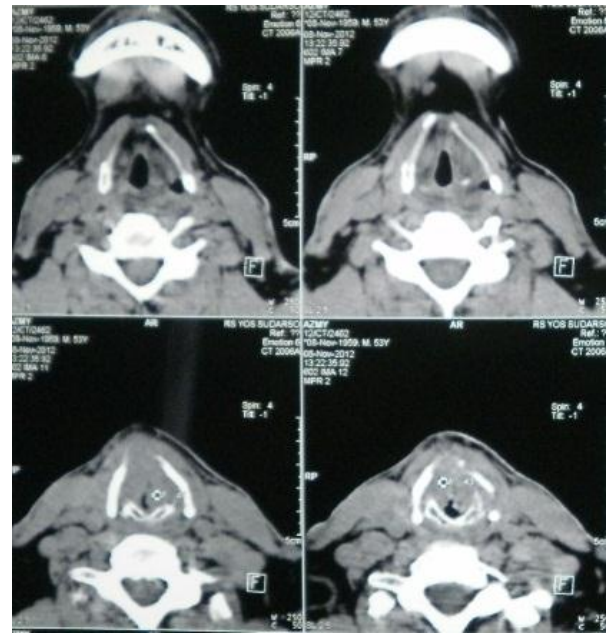

Gambar 3.TK potongan Aksial Laring

Hasil pemeriksaan histopatologi laring 5 November 2012(no PY 0878-12) tampak jaringan dengan permukaan dilapisi epitel berlapis gepeng yang mengalami proliferasi dengan sebagian inti sel pleomorfik, vesikuler, kromatin kasar, anak inti nyata dan diskeratosis. Pada stroma jaringan ikat dibawahnya tampak adanya kelompokan sel epitel gepeng yang sama dengan pembentukan mutiara tanduk. Diagnosis squamous cell carcinoma keratinized well differentiated. Pada tanggal 8 Desember 2012 akan dilakukan laringektomi total atas indikasi squamous cell carcinoma keratinized well differentiated glotis stadium III $\left(\mathrm{T}_{3} \mathrm{~N}_{0} \mathrm{M}_{0}\right)$ dengan persiapan ICU (Intensive Care Unit) dan persediaan darah.

Sebelum operasi dipasang pipa Nasogaster (NGT). Pasien tidur telentang dengan posisi leher hiperekstensi, dilakukan insisi berbentuk "U" mulai setinggi os hyoid dari kanan dan kiri ke daerah stomatrakeostomi, insisi diperdalam sampai menembus subkutis dan platisma, platisma diretraksi ke superior dan fasia dibebaskan, terlihat vena jugularis anterior dibebaskan dan diikat, otot strap (m.omohyoid, $\mathrm{m}$ sternothyroid dan m.sternohyoid) dipotong, kelenjar tiroid dibebaskan secara tajam dan tumpul dari kartilago krikoid dan cincin atas trakea, $\mathrm{N}$. laringeus rekuren diikat dan dipotong, pembuluh darah tiroid superior disisihkan ke lateral sehingga tampak otot konstriktor faring inferior. Setinggi kornu superior kartilago tiroid tampak pembuluh darah dan nervus laringeus superior diikat dan dipotong, setelah os hyoid tampak, dibebaskan dari perlekatannya (m. milohyoid, $\mathrm{m}$. geniohyoid, $\mathrm{m}$. digastrikus, $\mathrm{m}$. hipoglossus, m. stilohyoid) lalu os hyoid dibuang bersama laring, massa tampak memenuhi laring (glotis, supraglotis dan subglotis), trakea dipotong setinggi trakeotomi dan bagian posterior trakea yang tidak memiliki tulang rawan, dipisahkan dari esofagus dengan dilindungi klem kecil yang disisipkan diantara trakea dan esofagus untuk menjaga agar tidak menembus esofagus, kemudian esofagus terpapar, hipofaring dan esofagus dijahit berbentuk " $T$ " secara continuous inverted suturing meng-gunakan vicryl 4.0, pinggir stoma-trakea dijahit dengan silk 1.0, dipasang vaccum drain haemovac, luka insisi dijahit lapis demi lapis, operasi selesai.

Diagnosis pasca operasi adalah post laringektomi total atas indikasi squamous cell carcinoma keratinized well differentiated laring stadium III $\left(\mathrm{T}_{3} \mathrm{~N}_{0} \mathrm{M}_{0}\right)$. Pasca operasi pasien dirawat di Intensive Care Unit selama 3 hari. Tanggal 11 Desember 2012 (hari rawatan ke-3) cairan pada vaccum drain $\pm 3 \mathrm{cc}$ kemudian vaccum drain dilepas. Pada hari rawatan ke-7 (15 Desember 2012) jahitan kulit-stoma dilepas selang seling, injeksi gentamisin dihentikan, sedangkan seftriakson dan bromheksin dilanjutkan. Hari rawatan ke-10 (18 Desember 2012) tidak ada keluhan. Pemeriksaan regio coli anterior, luka operasi tenang, tanda infeksi tidak ada, terpasang kanul pada stoma, pasase udara lancar, jahitan stoma sudah dilepas.

Hasil pemeriksaan patologi anatomi (PJ 1947-12) dari sediaan tampak jaringan diliputi epitel respirasi, dibawahnya tulang rawan, jaringan ikat, tak tampak sel tumor ganas dalam sediaan. Dari sediaan trakea tampak jaringan dilapisi epitel respirasi yang sebagian mengalami dysplasia ringan dibawahnya tampak jaringan ikat dengan kelenjar dilapisi epitel kubis, tulang rawan, tak tampak sel tumor ganas. Dari sediaan massa tampak jaringan epitel respirasi dan dibawahnya tampak proliferasi sel-sel epitel berlapis gepeng yang pleomorfik, inti vesikuler, kromatin kasar, mitosis atipik, ditemukan banyak mutiara tanduk, sel ini tumbuh infiltratif ke jaringan ikat. Kesan squamous cell carcinoma keratinized well differentiated dengan kedua ujung sayatan bebas tumor. Hari rawatan ke11 saat dilakukan tes minum, tidak terlihat rembesan dari luka operasi, seftriakson, bromheksin dilanjutkan 
dan diet masih melalui NGT. Hari rawatan ke-12 (20 Desember 2012) keluhan tersedak tidak ada, luka operasi tenang, kemudian NGT dilepas, pasien diperbolehkan pulang dengan terapi tablet siprofloksasin 2x500mg, bromheksin 3x10ml, kontrol ke poli THT-KL 5 hari lagi. Tanggal 24 Desember 2012 (kontrol ke-1) demam tidak ada, gangguan menelan tidak ada. Regio colli anterior: stoma tenang, kanul terpasang baik, pasase udara lancar (Gambar 4). Tenggorok dalam batas normal.

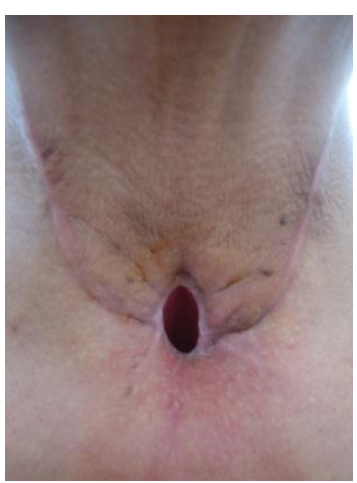

Gambar 4. Luka Operasi

Tanggal 6 Januari 2013 (kontrol ke-2) keluhan tidak ada. Pemeriksaan fisik telinga, hidung dan tenggorok dalam batas normal. Regio colli anterior: stoma tenang, kanul terpasang baik, pasase udara lancar, luka operasi baik. Pasien direncanakan akan dilakukan radioterapi, namun pasien masih berpikir dulu dengan alasan biaya.

\section{Diskusi}

Telah dilaporkan satu kasus laki-laki 53 tahun dengan karsinoma laring stadium III $\left(\mathrm{T}_{3} \mathrm{~N}_{0} \mathrm{M}_{0}\right)$ dengan hasil Patologi Anatomi squamous cell ca keratinized well differentiated yang ditegakkan berdasarkan anamnesis, pemeriksaan fisik, pemeriksaan penunjang berupa laringoskopi serat optik dan tomografi komputer laring serta hasil pemeriksaan histopatologi. Penatalaksanaan pada pasien dengan melakukan laringektomi total. Insiden tertinggi tumor ganas laring terjadi pada dekade 5-6. Angka insiden meningkat 3 kali pada kelompok umur 65 tahun keatas. ${ }^{12,13}$ Angka kejadian di Indonesia belum diketahui secara pasti. Kasus tumor ganas laring di bagian THT-KL RSCM periode 1980-1985 tercatat 144 kasus baru. ${ }^{14}$ Sedangkan di bagian THT-KL RSUP M. Djamil Padang kasus tumor ganas laring Januari
2011- Januari 2012 tercatat 13 kasus baru. Kasus tumor ganas laring pada laki-laki lebih tinggi dari perempuan. ${ }^{12-14}$ Angka kejadian di Negara Eropa lebih tinggi dari pada di Asia, rata-rata insiden pada laki-laki 2,5-17,1/100.000 penduduk. Di Kanada 6:1, Italia 32:1 dan Selandia Baru 6-7:1. Sedangkan di Surabaya dari 1996-2000 angka kejadiannya menempati urutan ke 34 dari keganasan di bidang THT-KL dengan persentase $10,2 \%-13,01 \% .^{12}$ Pada penderita keganasan laring, pemeriksaan awal harus teliti karena penentuan stadium tumor primer juga merupakan penentuan terapi dan prognosis. Evaluasi yang harus dilakukan adalah riwayat penyakit, pemeriksaan fisik, radiologi dan biopsi penting bagi penentuan stadium. ${ }^{1,12}$ Keluhan yang biasa ditemukan pada tumor laring biasanya suara serak, gangguan menelan, nyeri menelan, sensasi tersangkut di tenggorok, gangguan pernapasan sampai obstruksi jalan nafas, batuk darah dan nyeri alih pada telinga. 1,3,9,14 Pada tumor glotis gejala klinis pertama kali muncul adalah suara serak, serak lebih dari 3 minggu tanpa perbaikan dengan terapi konservatif patut kita curigai ada kelainan di laring. Pada tumor supra glotis dan sub glotis gejala awal adalah batuk dan gejala suara serak baru muncul jika tumor telah menginvasi pita suara. 2,3,14

Ketiadaan pembuluh limfe dan kurangnya vaskularisasi di daerah glotis menjelaskan mengapa pasien dengan tumor glotis biasanya hadir dengan keluhan bersifat lokal.3,9 Pasien merupakan perokok aktif dengan konsumsi rokok kretek 1 bungkus per hari selama \pm 30 tahun. Faktor predisposisi untuk terjadinya tumor ganas laring adalah merokok, penyalahgunaan alkohol dan genetik. 1,8,9,12,15-18 Individu yang mengkonsumsi rokok serta alkohol kemungkinan terjadinya tumor ganas laring menjadi lebih tinggi. 1,6-8,12 Dalam sebuah penelitian di Italia, $25 \%$ kasus tumor ganas laring pada pria terkait dengan riwayat konsumsi alkohol dan sekitar 75\% dikaitkan dengan merokok. ${ }^{16}$ Risiko untuk tumor ganas laring lebih besar untuk perokok yang telah merokok selama lebih dari 40 tahun atau untuk perokok lebih dari 20 batang per hari. Penelitian lain menunjukkan bahwa resiko akan cepat menurun setelah penghentian merokok dan penurunan angka resiko akan semakin besar jika perokok semakin lama 
seseorang berhenti merokok. ${ }^{15,16}$ Resiko tumor ganas laring berkurang $60 \%$ pada orang yang telah berhenti merokok selama 10 sampai 15 tahun dan berkurang lebih jauh pada orang yang telah berhenti merokok selama 20 tahun atau lebih. ${ }^{16}$ Diagnosis ditegakkan melalui pemeriksaan klinis menggunakan endoskopi kaku atau fleksibel sehingga memungkinkan penilaian menyeluruh keadaan permukaan tumor primer dan mobilitas pita suara. Ketika lesi primer laring ditemukan, disarankan untuk mendokumentasikan tumor yang berguna melihat tingkat penyebaran tumor. Hal ini sangat penting untuk menunjukkan lokasi asal dari lesi primer serta adanya perluasan tumor secara lokal ke struktur terdekat atau dari satu daerah ke daerah lain. ${ }^{1,12}$ Stadium tumor ganas laring ditentukan melalui klasifikasi TNM, menurut American Joint Committee on Cancer (AJCC) 2010.12,19Tumor primer $(\mathrm{T})$ pada kasus ini yaitu daerah glotis dengan tumor terbatas di laring dengan fiksasi pada korda vokalis, belum menembus kartilago tiroid $\left(\mathrm{T}_{3}\right)$. Pada pemeriksaan KGB leher tidak ada pembesaran $\left(\mathrm{N}_{0}\right)$. Pemeriksaan darah lengkap, faal hepar, fungsi ginjal dan foto polos toraks dalam batas normal $\left(\mathrm{M}_{0}\right)$.

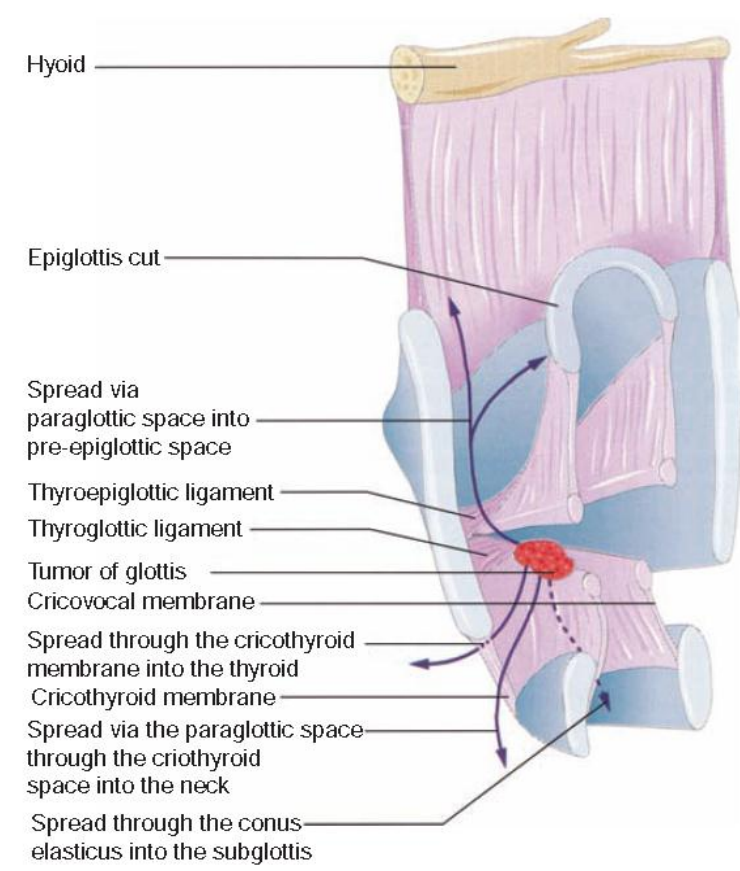

Gambar 5. Proses penyebaran tumor glotis ${ }^{9}$

Struktur laring (gambar 5) seperti membran dan tulang rawan memainkan peran penting dalam penyebaran tumor laring: 1) conus elasticus menghambat penyebaran tumor ke inferior glotis sehingga penyebaran ke subglotis terjadi pada stadium lanjut, 2) tumor yang melibatkan komisura anterior biasanya menyebar ke tulang rawan tiroid karena pada daerah ini lebih tipis di garis tengah sedangkan daerah lateral lebih tebal, 3) ruang paraglotis mengandung otot vokalis lebih tipis di ruang krikotiroid lateral sehingga tumor glotis dapat menyebar ke leher melalui rute ini sehingga tumor ganas glotis dapat terdiagnosis tidak tepat karena mengevaluasi penyebaran ke daerah ini sulit. Ruang paraglotis terhubung dengan ruang preepiglotis dan tumor glotis menyebar ke supraglotis melalui rute ini. 4) tumor ganas epiglotis dapat menyebar langsung ke preepiglotis melalui perlekatan tulang rawan epiglotis sehingga ruang ini harus benar-benar tereseksi sewaktu laringektomi supraglotis. ${ }^{9,12}$

Tumor ganas laring daerah glotis biasanya pada lokasi 2/3 anterior sedangkan daerah supraglotis tersering di epiglotis. Daerah supraglotis memiliki banyak aliran getah bening dan bermuara ke kelenjar getah bening leher level II sedangkan daerah glotis tidak memiliki dua saluran getah bening.9,12 Ligamen Broyles merupakan struktur yang berfungsi sebagai pertahanan, jika struktur ini terkena berarti tumor telah menginvasi kartilago tiroid dan jika sudah menginvasi kartilago tiroid maka stadium tumor ( $\mathrm{T}$ ) berubah menjadi T4. ${ }^{12,19,20}$

Lebih dari 95\% kasus tumor ganas laring merupakan karsinoma sel skuamosa. Hal ini dikarenakan laring merupakan organ yang dilapisi epitel skuamosa yang berubah bentuk karena pajanan trauma atau akibat rangsangan karsinogenik. Perubahan epitel normal menjadi ganas biasanya diawali oleh leukoplakia, hiperplasia, keratosis non atipik, keratosis atipik, karsinoma insitu dan karsinoma mikroinvasif. ${ }^{7,9,12}$ Selain karsinoma sel skuamosa bentuk histopatologis lain adalah verrucous ca, pseudosarkoma, dan adenokarsinoma. ${ }^{9,12}$

Menurut AJCC stadium pasien adalah $\mathrm{T}_{3} \mathrm{~N}_{0} \mathrm{M}_{0}$. Metastasis jauh umumnya terdapat pada pasien yang memiliki limfadenopati regional yang besar. Angka kejadian metastasis regional pada $\mathrm{T}_{3}$ dan $\mathrm{T}_{4}$ berkisar 20-25\%. ${ }^{12,14,19}$ Metastasis jauh yang paling umum adalah ke paru dan tulang, sedangkan ke hati lebih jarang lagi. Metastasis ke kelenjar getah bening mediastinum dianggap metastasis paling jauh. ${ }^{12,14,19}$ 
Sebagian besar kasus (69\%) ditemukan dalam stadium lanjut ( $\mathrm{T}_{3}$ atau $\left.\mathrm{T} 4\right)$. Tindakan operatif dilakukan sebagai pilihan utama pada $57 \%$ kasus (259 pasien), radioterapi saja dilakukan pada 124 pasien (27\%) dan kemoradiasi pada $16 \%$ kasus (68 pasien). ${ }^{20}$ Salah satu studi terhadap 451 pasien tumor ganas laring dari 1985-2002 didapatkan angka harapan hidup 5 tahun pada stadium I 85\%, stadium II 77\%, stadium III $51 \%$ dan stadium IV 35\%. ${ }^{20}$

Angka kelangsungan hidup rata-rata yang diamati pada pasien tumor yang bersifat lokal adalah 115 bulan, yang menyebar secara regional 43 bulan dan dengan metastasis jauh 11 bulan. $^{3}$

Pasien tumor ganas laring memiliki angka rekurensi yang lebih rendah dibandingkan tumor kepala leher lain. ${ }^{21}$ Pasien dengan tumor ganas glotis juga mempunyai angka harapan hidup lebih baik dan rekurensi yang rendah dibandingkan tumor supraglotis dimana penyebaran regional lebih sering terjadi. ${ }^{20,21}$

Lacy dan Pricillo seperti dikutip Francis ${ }^{21} \mathrm{dkk}$ menemukan perluasan tumor saat terjadi kekambuhan menjadi faktor prognostik yang signifikan dalam memprediksi angka kelangsungan hidup pada pasien dengan tumor ganas laring. Prognosis keseluruhan baik dengan angka harapan hidup yang terbaik pada pasien tumor ganas glotis dibandingkan supraglotis dan subglotis. Hal ini dikarenakan secara anatomis, glotis tidak memiliki saluran limfe serta vaskularisasi yang lebih sedikit dibandingkan supraglotis dan subglotis. 3,9,20,21 Angka harapan hidup 5 tahun jika dibandingkan dengan jenis histopatologi tumor, squamous cell ca $68 \%$, verrucous ca $95 \%$ dan yang terendah adalah small cell neuroendocrine ca (5\%). ${ }^{9}$

Laringektomi total adalah prosedur pembedahan radikal dimana dilakukan pengangkatan seluruh struktur laring. Prosedur operasi ini digunakan pada penatalaksanaan tumor ganas laring lanjut atau prosedur lanjutan ketika operasi laringektomi parsial dan radioterapi sebelumnya gagal. 1,10,12,14,22

Jika pasien sudah pulih sadar setelah operasi, pemberian makanan cair per NGT sudah dapat dimulai, karena NGT dekat dengan insisi internal diharapkan jangan telalu banyak memanipulasi NGT karena ditakutkan akan mencederai luka operasi. ${ }^{2}$ Diet pasien pasca operasi dimulai makan dengan makanan konsistensi cair selama 5-7 hari. Pasien harus menghindari mengunyah (oral feeding) selama 7-14 hari agar tidak berefek buruk pada proses penyembuhan luka. Biasanya NGT dipasang sampai 7-10 hari. ${ }^{2,22}$ Komplikasi dari laringektomi total yang mengancam hasil operasi adalah fistel faringokutan, infeksi luka, flap yang nekrosis dan hematom. ${ }^{22,23}$ Untuk itu perawatan luka operasi memegang peranan penting dalam proses penyembuhan luka dan pencegahan terjadinya fistel. Salir harus diperhatikan setiap 8 jam untuk memastikan berfungsi baik agar mencegah terbentuknya hematoma, seroma dan infeksi. Tanda-tanda luka insisi yang terinfeksi harus diperhatikan seperti kemerahan, udem, dan basah. Oral hygine yang baik pasca operasi sangat penting untuk mengontrol infeksi dan mencegah bau mulut. ${ }^{2}$ Fistel faringokutan dapat muncul pada daerah insisi operasi, paling sering pada minggu pertama setelah operasi. Sesuai dengan lokasinya, fistel faringokutan dan orokutan merupakan fistel tersering pada pasien dengan reseksi yang ekstensif, faringektomi dan prosedur operasi setelah gagal kemoradiasi. ${ }^{22}$

Masalah menelan muncul setelah laringektomi karena adanya aliran balik ke faring saat proses menelan. Residu yang terlihat didaerah faring saat pemeriksaan dengan video-fluoroskopi merupakan tanda utama penurunan tekanan otot faring. Penurunan fungsi faring ini dikarenakan hilangnya gerakan anterior dan superior faring selama proses elevasi hyolaryngeal dan retraksi dasar lidah yang diperlukan untuk membantu pembukaan Upper Esophageal Sphincter (UES). Penyebab potensial stasis makan di faring meliputi semua hal yang dapat merusak kontrol neuromuskular dinding faring atau dasar dari otot lidah, termasuk edema pasca operasi dan reseksi bedah yang akibatkan gangguan pada volume dan kekuatan gerak palatum. Striktur dapat terjadi di faring akibat penutupan defek operasi hipofaring yang terlalu ketat. Masalah pada proses menelan ditandai dengan keluhan mengganjal di tenggorok. Waktu transit faring menjadi dua kali lebih sehingga memperpanjang waktu makan pasien. ${ }^{22}$

Jenis makanan cair membantu membersihkan sisa makanan yang mengganjal. Selain itu, strategi kompensasi, seperti rotasi kepala atau latihan menelan dengan bantuan, efektif dalam meningkatkan tekanan faring dan membantu bolus 
melewati faring. Menelan dengan cara menarik lidah kemudian menahannya selama proses menelan dapat dilakukan untuk memaksimalkan proses menelan pasien. ${ }^{22}$

Pasca laringektomi total, dokter dan petugas medis berperan dalam membantu komunikasi pasienkeluarga. Penggunaan alat bantu menulis, petunjuk bergambar dan papan tulis bahkan isyarat jari sangat berperan dalam berkomunikasi.2,14 Akibat proses pengangkatan laring dibutuhkan beberapa metode untuk memproduksi suara seperti wicara esofagus, penggunaan laring artifisial dan transesophageal puncture (TEP). ${ }^{2,24}$ TEP yaitu membuat fistula pada dinding yang memisahkan trakea dengan esofagus. Pada fistula ini diletakkan protesa katup satu arah yang memungkinkan udara dari paru melewati esofagus dan menggetarkan segmen faring-esofageal sehingga menghasilkan suara. ${ }^{2,24}$ Teknik TEP ini sudah pernah dilakukan di RS. M. Djamil dengan menggunakan protesa Provox. Pertimbangan pemilihan protesa meliputi beberapa segi seperti keinginan pasien akan kualitas suara yang dihasilkan, kemudahan dalam perawatan protesa, ketahanan alat dan harga alat. Penyulit pasca insersi Provox antara lain kebocoran protesa, kebocoran disekitar protesa, protesa tersumbat sampai terbentuknya jaringan granulasi di tempat insersi protesa. ${ }^{24}$

\section{DAFTAR PUSTAKA}

1. Shah J, Patel SG, Singh B. Larynx and Trachea. In: Shah J, Patel SG, Singh B, editors. Head and Neck Surgery and Oncology. Philadelphia: Elsevier Mosby. 2012. p. 811-992.

2. Bressler C. Post-operative care of the Laryngectomy Patient. Perspectives. 2000; 2(1): 4-7.

3. Piccirillo JF, Costas I. Cancer of the Larynx SEER Survival monograph. National Cancer Institute 2001. p. 67-72.

4. Mulyarjo. Berbagai masalah dalam pengelolaan tumor ganas laring di Surabaya. Pidato pada peresmian jabatan guru besar dalam IImu Penyakit THT pada Fakultas Kedokteran Universitas Airlangga. 1998. p. 1-27.

5. Vasan NR. Cancer of the Larynx. In: Lee KJ, ed, Essential Otolaryngology Head and Neck
Surgery, $9^{\text {th }}$. New York, McGraw-Hill, 2008, p. 676-06.

6. Iqbal N. Laryngeal Carcinoma Imaging. Updated 2011 May 27; Cited 2013 Jan 20. Available from: http:// emedicine.medscape.com/article/383230.

7. Tucker HM. The Larynx, $2^{\text {nd }}$ ed. New York: Thieme Medical Publishers; 1993. p. 287-324.

8. Spiric P, Spiric S, Stankovic M. Modified Technique of Total Laryngectomy. Acta Medica Medinae. 2010; 49(4): 39-42.

9. Sheahan P, Ganly I, Evans PHR, Patel SG. Tumors of the larynx. In: Montgomery $P Q$, Evans PHR, Gullane PJ, editors. Principles and practice of head and neck surgery and oncology. Florida: Informa health care;. 2009. p. 257-90.

10. Maharjan. Early complication of total laryngectomy: A Retrospective study. SOL Nepal, Vol. 1, No.2, July-Dec 2010, 17-18.

11. Mendenhall WM, Amdur RJ, Morris CG, Hinerman RW. $\mathrm{T}_{1}-\mathrm{T}_{2} \mathrm{~N}_{0}$ Squamous Cell Carcinoma of the Glottis Larynx Treated with Radiation Therapy. JclinOncol. 2001; 19(20):4029-36.

12. Romdhoni AC. Aspek klinis dan diagnosis keganasan laring. Dalam naskah lengkap update in management of sinonasal and laryngeal cancer. Surabaya. 2010. 109-19.

13. Laryngeal Cancer: Cancer in New Zealand. 2002. (Cited 2013 Jan 20). Available from: http://moh.govt.nz /19laryngeal.pdf. 2002.

14. Hermani, B. Laringektomi. Dalam naskah lengkap Simposium bedah kepala leher. Jakarta, 2000. 21-7.

15. Ramroth $\mathrm{H}$, Dietz $A$, Becher $H$. Intensity and Inhalation of Smoking of Laryngeal Cancer. Int.J.Environ. Res.PublicHealth. 2011; 8: 976-84.

16. Pelucchi C, Gallus S, Garavello W, Bosetti C, LaVecchia C. Cancer risk associated with alcohol and tobacco use: focus on aerodigestive tract and liver. Alcohol Research and Health. 2006; 29(3): 193-8.

17. Centers for Disease Control and Prevention. Tobacco use and secondhand smoke: Impact on cancer. Available from: http:// www.cdc.gov/tobacco/campaign.24/7. Diakses tanggal 9 Januari 2013. 
18. Cancer Research UK. Risks and causes of laryngeal cancer. Available from: http//www. Cancerresearchuk. org/cancer-help/type/larynxcancer. Diakses tanggal 9 Januari 2013.

19. Edge SB, Byrd DR, Compton CC, Fritz AG, Greene FL, Trotti A. AJCC Cancer Staging Manual, $7^{\text {th }}$ ed. New York, Springer;. 2010, Chapter 5: Larynx, p. 57-67.

20. Gourin CG, Conger BT, Sheils C, Bilodeau PA, Coleman TA, Porunsky ES. The Effect of Treatment on Survival in Patients with Advanced Laryngeal Carcinoma. Laryngoscope. 2009; 119: 1312-17.

21. Francis DO, Yueh B, Weymuller EA, Merati AL.
Impact of surveillance on survival after laryngeal cancer in the Medicare population. Laryngoscope. 2009; 119: 2337-44.

22. Landera MA, Lundy DS, Sullivan PA. Dysphagia After Total Laringectomy. Available from: http://journals.asha. org/perspectives/terms.dtl.

23. Kazi RA. Laryngectomy Guide Book. Available from: http.www.asha.org. Accessed January 9, 2013.

24. Yusuf M. Rehabilitasi penderita pasca laringektomi total dengan alat bicara tiruan. Dalam naskah lengkap update in management of sinonasal and laryngeal cancer. Surabaya, 2010. 137-46. 